John E. Tyler III'

\title{
Less than Meets the Eye: an Analysis of Robert Reich's Just Giving: Why Philanthropy Is Failing Democracy and How It Can Do Better (2018)
}

\author{
${ }^{1}$ Ewing Marion Kauffman Foundation, 4801 Rockhill Rd, Kansas City, MO 64110, USA, E-mail: jtyler@kauffman.org
}

DOI: $10.1515 / \mathrm{npf}-2019-0026$

For more than ten years, Stanford Prof. Rob Reich has lamented that foundations have been allowed to be subsidized, unaccountable, opaque, and powerful - as he and others conceive of foundations and their environment. Given more than a century of persistently similar criticisms and condemnations, he decries the lack of attention given to a theory of philanthropy, as if suggesting that greater attention in the past might have reined in the apparently corrosive effects of foundations on our democracy and society over time and today. He also seems to urge that greater attention in the present, especially as a political theory of philanthropy, will prevent or at least minimize their future corrosive effects.

His new book is his most extensive effort to call attention to that need and to try to begin filling the void. Unfortunately, the book is too confusing, nuanced, and incomplete to be considered an effective theory of philanthropy or to achieve other overtly stated purposes, except for bringing useful attention to the value of discussions about having a coherent theory of philanthropy and/or foundations.

The book positions its purposes as structured on five pillars: (1) philanthropy is repugnant to democracy as described; (2) philanthropy is an "artifact" of the State; (3) foundations are opaque and unaccountable; (4) donor intent and perpetuity are subversive; and (5) the charitable deduction is a financial subsidy with no redeeming value. However and as is shown below, each pillar leaves out critical elements and analysis, and the vacillation between abstraction and practice without consistently noting the switches or fully presenting either creates confusion.

In other words, while the pillars may appear to be made of marble, there is more than enough papier-mache to undermine their structural, weight-bearing integrity such that the roof does not remain aloft.

That roof consists in part of identifying two possible roles - and only two roles - as acceptable for foundations in democracy: supporting discovery and advancing pluralism. While both roles are appropriate for foundations and philanthropy, their positioning in the book neglects important chronologies and histories and suffers from other missing substantive analyses that counter bases for restricting foundations to these and only these functions.

Finally, the book is too confusing and nuanced about its purposes and path. It overtly states it is advocating for or presenting a political theory of philanthropy, but its major criticisms and roles most directly apply to foundations specifically, not philanthropy more broadly. The exception may be the book's overarching theme that the charitable deduction is "indefensible" (134). Moreover, the book overall appears actually - but subtly to be more critical of and more of a commentary on America's representative democracy rather than of either foundations or philanthropy. None of this is bad or wrong in itself. But the seeming disconnect between overt objectives, actual presentation, and implicit purposes can leave a reader wondering which path they are on, where they have been, and where they are being led.

The book does succeed in drawing useful attention to its topics. As members of a society and a representative democracy, we benefit from these points of view, discussions of, and hopefully even counters to them. The book also succeeds in other ways that are worth mentioning.

Among the book's other successes is an interesting perspective of philanthropy in Ancient Athens and as developed and practiced in Islam throughout history and into the present. Another is a relatively concise summary of the theoretical bases for the charitable deduction and commentary on them. Two other contributions are the book joining in the principled call for making the charitable deduction available to all taxpayers - not just to itemizers $(81,121)$ - and its presentations on the value of pluralism to and its essential contributions to furthering our representative democracy.

I do not lightly undertake to critique the work of a renowned, highly regarded, and widely respected Stanford professor. My hope is that this essay will be received and responded to in the spirit in which it is offered,

John E. Tyler III is the corresponding author.

(c) BY (c) 2019 Tyler, published by De Gruyter.

This work is licensed under the Creative Commons Attribution 4.0 Public License. 
which is appreciation for the questions asked, respect for the positions asserted, but substantial concerns about what I perceive as critical gaps and missing information and perspective. This essay also is an acceptance of the book's invitation to engage the posited discussion and is presented from a seemingly shared perspective of believing that philanthropy generally and foundations particularly can be and should do better in any number of ways.

With that in mind, what follows is a more thorough analysis of the book's five pillars, two proposed roles for foundations, and the confusing nature of the book overall.

\section{Pillar 1 of 5: Philanthropy is Repugnant and a Menace}

As the book's subtitle decrees, it begins from a place in which philanthropy is and has been presumptively failing democracy as described in the book ${ }^{1}(5,136-137)$. That description fundamentally depends on all citizens possessing "an equal opportunity for political influence and participation," (136) which on the surface sounds sufficiently equitable, just, and egalitarian.

Elucidating that description of democracy are the book's repeated correlations of wealth with disproportionate political influence and how the book references equality in terms of material wellbeing. Especially given those overlays, the description of democracy as grounded on "equal opportunity" for influence and participation is nebulous enough to allow for an interpretation that requires equal distributions of material goods, resources, and assets - along with equal distributions of intellect, judgment, charisma, community standing, reputation, and other intangible personal characteristics.

The book's overt presumption of philanthropy "failing democracy" is declared without apparent counterpoint or objectivity. There just seems to be conclusion, and not only in the subtitle.

The early, context-setting pages of the book invoke from hundred-year old characterizations of specific foundations of the time - not philanthropy as a whole as the book's subtitle suggests. Even then, the characterizations reference only one particular foundation or type - not necessarily all foundations - as being "repugnant" to democracy and a "menace" to society $(4-5,138)$. These references do not simply provide historical context from the origins of the Rockefeller Foundation; rather, these references seem to be conveying a belief that these characterizations broadly apply to foundations today.

The book also invokes Machiavelli warning against the pernicious effect of "'works that appear merciful'" and beyond condemnation becoming "'cruel and very dangerous for a republic'" (108-09), which is only a short step away from Orestes Brownson's declaration in the 1850s that philanthropy is Satan's "favorite guise in modern times."

It is one thing for donors and those who work in philanthropy to internalize these observations as admonitions towards humility and care, which they should. It is quite another to generalize them as predisposing, genetic features of all foundations and/or philanthropy. The book seems to do the latter.

The subtitle forecasts possibilities that philanthropy might be able to operate in practice in ways that would allow it to "do better." Not reach redemption - much less make productive contributions - but "do better." Thus and given the context of the preceding paragraphs, the book's aspiration appears to be to render philanthropy less repugnant or menacing.

So we know from the book's cover and early pages, that the book is not a glorification of philanthropy, at least not as practiced in the United States. To its credit, it makes this point overtly (22), including referring to the "current practice of state-supported philanthropy, especially in the United States," as "indefensible" (134). We, therefore, also can surmise that we should not expect the analysis to be objective, which seems like an inauspicious place from which to begin designing a theory.

The book does not present, much less refute, the strong arguments in favor of foundations or philanthropy as having redeeming value to our democracy, except as they fit the two limited roles assigned later. Nor does the book present the most meaningful arguments that support places for foundations and philanthropy in democracy or America's representative approach to it. Or if it does, such allusions are superficial, well buried, and/or presented as straw men.

The book also does not seem to appreciate the irony in how it invokes democracy but neglects to connect how America's democracies operated in practice during the period of deep cynicism over one hundred years ago $(6-7,138-39)$. That is, on one hand, through democracy Congress prevented a federal charter for the Rockefeller Foundation. On the other, democracy permitted its creation under state law.

Furthermore, the book neglects how America's democracies - state and federal - have given credence to, reaffirmed, and critiqued both philanthropy and foundations since that time, thereby giving at least some degree of democratic imprimatur of presumed consistency therewith. That affirming context is provided no 
where, and the reasons for its absence emerge in implications that the book may be less about critiquing philanthropy and foundations and perhaps more so an attack on America's representative democracy.

\section{Pillar 2 of 5: Philanthropy is an "Artifact of the [S]tate"}

The way in which the book does relate philanthropy to our democracy is to position it as an "artifact" of the State - not of democracy but of Government, as if they were two independent, distinctive things. According to the book, philanthropy is or should be considered as enabled by the legal infrastructure provided by and thus as an "artifact of the [S]tate" $(26,63)$. As such, the book suggests that philanthropy is or should be submissive and subservient to the good graces of the State; thus also in some way appealing to the power in the State to do away with philanthropy and foundations altogether on its whim.

An alternative perspective neglected by the book is that certain liberties, rights, and processes that are at the core of American democracy pre-exist our State and pre-date the infrastructure on which the book relies. Moreover, this alternative point of view recognizes that these principles serve in part to limit the power of the State and some of the downsides of democracy generally, certain of which the book eloquently presents.

This view further acknowledges that there is a relationship between philanthropy and these principles and, as such, the legal infrastructure may actually proceed from and be in furtherance of them rather than being magnanimously bestowed from on high.

Instead of addressing this alternative point of view, the book at best dismisses it $(28,200)$ as overemphasizing liberty at the expense of equality (68-70). That dismissal and treatment of philanthropy as an "artifact of the [S]tate" seem to position the preceding principles - and philanthropy to the extent it is related to them - as subservient to and supplicant of the State rather than the State as a guardian of those principles and the means by which they are exercised and expressed, including through philanthropy and foundations.

In some ways, this context might be summarized by the question - which came first: philanthropy or State recognition (or perhaps expropriation) of it? Given the interesting chapter that discusses the history of philanthropy in ancient Athens and throughout Islam more than a millennium before the founding of America, it sure seems like philanthropy came first. More aligned to the American experience of philanthropy, colonial and early U.S. exercises of it by Faneuil, Tappan, Girard, Franklin, and many others give further credence to the correct sequencing.

\section{Pillar 3 of 5: Foundations are Opaque and Unaccountable}

The book continues by asserting that foundations operate with only minimal and ineffective transparency imposed by law $(7,145)$. It complains that our democratic systems allow foundations to operate with no accountability; they have no shareholders, customers, or electorate. It dismisses voluntary openness and responsiveness as merely "idiosyncratic" (147), from which a reader may infer that what emerges is a bastion for presumptive abuse, damage, and misery forcibly imposed on society as plutocratic exercises of unmitigated power with little or no redeeming value.

To be clear, the book seems unclear about whether its negative views run to the work that foundations do or the fact that foundations can do their work at all, as it conceives of that work. The book is clear about the inappropriateness of the charitable deduction. The book leaves an impression that, unless regulated as proposed, it does not view foundations positively in general and especially with regard to their existence in the democracy it describes.

The book further suggests that foundations thoughtlessly impose their uninformed will on the public unilaterally without (i) support from or action by others who agree with them, (ii) vetting or overcoming opposition, or (iii) legitimately engaging our democracy and its underlying people and processes. As is the case with other pillars, the book is incomplete in this regard as well.

For instance, the book makes no mention of how foundations often provide grants to and/or engage researchers and others to develop and advance understandings of the program areas on which they are focused - pro and con. It ignores that the organizations that receive grants have positions that align with those of the foundation; sometimes those same organizations are even responsible for planting and nurturing the ideas with the foundation in the first place.

The book further glosses over that, when foundations engage with policy makers and their staffs, they educate, inform, and advocate. It is the policy makers who act to create and institute policy - that is, it is the actions of democratically elected and/or hired professional staffers responsible for acting on behalf of the People. Sometimes they agree with foundations; many times they do not. 
Contrary to what the book seems to want readers to conclude, the work of foundations is hardly unadulterated exercise of power or unaccountability run amok.

The incompleteness, lack of clarity, and inferences in the book make it hard to evaluate or respond to the positions taken in the book. Even so, elsewhere ${ }^{2}$ I have considered how transparency and accountability intersect with foundations. The issues are far more nuanced and complicated than the book seems to presume, especially as a matter of State imposed mandates that the book might be interpreted as supporting. The book's apparent over-simplification of these issues artificially elevates the points it tries to make and is another example of the book's ambiguous vacillations between theory and practice.

\section{Pillar 4 of 5: Donor Intent and Perpetuity Subvert Democracy}

Part of the book's nearly sweeping disdain seems further derived from the ability of foundations under state laws to exist in perpetuity and because of how our representative democracies permit them to be guided by donor intent, especially after the donor's death - even protecting that intent at law. The book thoughtfully positions that disdain as standing on the shoulders of Anne-Robert Turgot and John Stuart Mill.

Unfortunately, the book fails to account for practices and processes in the law by which the asserted dangers of donor intent and perpetuity are not as they are presented.

For one thing, many if not most foundations are set up by their donors to formally and irrevocably operate within the bounds of what is broadly permissible under 501(c)(3) without any further legal limitations or restrictions of intent. Even the Rockefeller Foundation, as the book describes, was set up to "benefit mankind" (2). That general approach hardly seems like it should give rise to worries about the "dead hand" of donor dominance and inflexibility over time, including after a donor's death.

Second, there is ample evidence as the book acknowledges (50, citation omitted) that second, third, and subsequent generations of boards, management, and staff stretch donor intent to comport with their own understandings, which suggests an absence of problems with donor intent being too rigid. Perhaps if there were greater enforcement of restrictive applications of donor intent and evidence of a critical mass of problems therewith, the case of the "dead hand" might be more appealing. In their absence, the bigger danger may be the specter of theory overtaking reality and ultimately that chasing ghosts causes more harm than good.

Finally, the book neglects the doctrine and procedure in law (and practice) by which a court can authorize deviating from donor intent in certain circumstances. This helps mitigate potential for certain possibly destructive or wasteful tendencies of donor intent and/or perpetuity unencumbered. Absent evidence to the contrary, the infrequency with which this doctrine and procedure are invoked seem less likely to be matters on which to ignore it as the book seems to do and more likely to reflect a lack of problem in this regard.

\section{Pillar 5 of 5: The Charitable Deduction as Financial Subsidy}

The book's final pillar regards the financial tax subsidy of the charitable deduction. The book's most consistent theme - and perhaps the cornerstone of any recoverable theory - is that the charitable deduction is not necessary or appropriate for philanthropy or foundations. The book makes three arguments for doing away with that subsidy.

First, the book refers to history and argues that no charitable deduction was available for philanthropy and foundations that predate the federal income tax. Of course, there also was no federal income tax against which to apply such a deduction so relying on the absence of the deduction seems nonsensical.

Second, the book thoughtfully summarizes the three arguments generally posited for the charitable deduction. The book dismisses two of these almost out of hand, and the third - based on the essential role of pluralism in democracy - the book finds relevant for other reasons but rejects as justification for tax deductions.

The book continues by positioning the charitable deduction as fundamentally arbitrary and unfair (80) in favoring the wealthy and their preferences. While the book makes a principled argument that all taxpayers should be able to deduct their charitable contributions $(81,121)$, the book's conclusory declarations do not follow.

For a start, the standard deduction by which most taxpayers forgo an explicit charitable deduction is a way of simplifying tax filing for those taxpayers. It is not necessarily an effort to preference itemizers or "penalize" non-itemizers (78), who claim the standard deduction whether or not their deductible expenditures rise to that amount. Unfortunately, that effort to prioritize simplicity and efficiency for most taxpayers has left an opening for contorting those objectives and manufacturing imaginary preferences with populist appeal. 
In addition, the charitable deduction as applied today is an artifact of the progressive tax system by which tax and deduction rates increase as taxable income increases. The goal is that those who earn more money pay taxes at higher rates as their incomes rise. Contrary to portrayals in the book, applicable rates in this progressive system are not a conspiracy to favor those who earn more (by subjecting them to higher tax rates) or an intentional bias against those who earn less (by having them pay taxes at lower rates).

Thus, the charitable deduction is not unfair and arbitrary as portrayed in the book. As with other aspects of the book, it hereto neglects important features and roles for the charitable deduction that justify its presence and continuation.

The book discusses how Congress introduced the charitable deduction as an important corollary to the then newly imposed federal income tax (149). However, it glosses over that the deduction was not an incentive but was introduced to protect against possibilities that the newly imposed income tax would negatively impact giving to organizations doing charitable work.

The book also discusses important roles for civil society served by the charitable deduction, especially its essential value to pluralism, tempering of government orthodoxy (155), being a buffer and/or countervailing force to the State (181), and serving as alternative or complementary mechanisms to public efforts (181). In addition, civil society facilitates ways for speaking and assembling freely, and supports structures for citizens to petition their government as well as to pursue private efforts to identify and address a variety of public problems and opportunities that affect them. After all, as the book notes, the State has the power to "freeze civil society" (181) and thus the efforts that comprise it.

However, in the book these features of the charitable deduction stand alone and disconnected. In reality, they operate to position the charitable deduction as a critical boundary-setting device that helps restrict the State's ability to exercise its power to freeze. In that regard, the charitable deduction uniquely helps protect against State co-opting of civil society for its own ends rather than those of the People and our Posterity.

The book's failure to connect those features is another example of its incompleteness, thus crumbling another pillar.

\section{A Role for Foundations: Pluralism}

The book builds on its conceptions of civil society and other arguments to identify two roles - and only two roles - for foundations (although apparently not philanthropy) in a democracy, albeit without tax deductions (15266). One is to further degrees of pluralism, which the book at one early point finds appropriate for individual philanthropy but not apparently foundations (19). The other is to facilitate discovery. In an enticing but ironic gesture of magnanimity, the book suggests that these roles might not only be tolerable in a democracy but might even not be repugnant.

In furtherance of pluralism, the book recognizes that foundations can help decentralize processes for defining and producing "public goods" (155). They can "temper[] government orthodoxy in a democracy" (155). They have the potential to be - but in their current form are not (182) - good sources of capital for civil society to be a buffer or countervailing force against the State (181).

The book thus reasons that, through its pluralism argument, the book "confers" legitimacy (153) and "turn[s]" the previously criticized foundation features of autonomy and lack of accountability "from a defect into an important virtue" (156).

This is another example of questionable sequencing or chronology. After all, which came first: how accountability and autonomy operate in foundations in service to pluralism or the book's conferrals and re-positioning of them as "virtues"? Did these features not allow foundations to advance pluralism before the book or earlier writings in this regard? Were they not productive before? Did they only become valuable and "virtues" upon being so positioned?

Even so, the book's support for a role for foundations in fostering pluralism is tepid at best because of how it portrays foundations in practice as serving only the plutocratic preferences and priorities of the wealthy as if unmitigated exercises of power.

As so understood, those who are wealthy must be universally aligned on their respective purposes, priorities, and means of accomplishing them. Furthermore, foundation missions and work must not align with any one else's preferences or priorities - only those of people with wealth, none of whom would apparently take a view contrary to others with wealth. Not grantees and their respective staffs, boards, funders, and constituents; researchers; or policy makers. It is as if only people with wealth care about ensuring quality education for all, improving health care for all, various religious and faith traditions, jobs and economic mobility, marriage and civil rights issues, environment, and other missions that foundations support. Or if there is overlap with those 
without wealth, implications are that such overlap must be idiosyncratic, accidental or disingenuous rather than fundamentally shared and mutual.

The book further neglects that there are intervening policy makers, elected and appointed officials, procedural protections, skeptical journalists, critical academics, an interested public, and others through which any such preferences would need to navigate before being broadly instituted. The book's inference is that foundations can dictate edicts and thrust a will upon society unvetted, uninhibited, and against its will.

That characterization may be countered as extreme and with the suggestion that the problems are not with edicts but with disproportionate influence. Of course, that is not how the problems are generally positioned in the first place given invocations to foundation "power." Even so, the suggestion would be that the wealthy directly or indirectly buy decision-makers and those who influence them, all of whom must be corrupt or lacking free will. If either is the case, then the problem is not with foundations, the wealthy, or democracy generically but with human nature. And an entirely different book is needed.

\section{A Role for Foundations: Discovery}

The book posits a second role for foundations based on what it terms the "discovery" mode. In this role, society and democracy benefit from observations that the lack of accountability and the long time horizon over which foundations can operate support experimentation and contributing risk capital to counter democratic tendencies towards short-termism and presentism $(23,162)$. As with the pluralism role, this discovery role seems to "turn" pre-existing, otherwise historically negative features into "virtues."

According to the book, this role would tolerate only those foundations that are large (e. g., \$50 or \$100 million plus) and professionally staffed because foundations that are small and/or not staffed by professionals could not deal with the complexities of this discovery mode. As a corollary, the book encourages accountability by having external panels of social science experts review foundation strategies, experiments, and results (163).

As the book notes, foundations do fill and have filled this discovery role (164) to degrees. The book justifiably continues, though, that foundations generally are not aggressive enough in doing so (167). Foundations can and should do more in this regard.

However, the book fails to account for the fact that among reasons foundations may not be as aggressive as they could be in pursuing discovery is that they are so often attacked and criticized when they try to be even somewhat aggressive. Among the ironies is that those attacks are a means by which foundations are held accountable and are often stifled. Given how effective the critiques apparently are in contributing to foundation reluctance to innovate or "discover," it sure seems as if foundations are not unaccountable, and in light of the book's critiques of foundation deficiencies in this discovery role, it could logically follow that foundations actually may be too accountable for the discovery role to flourish.

\section{Theory: Of Philanthropy? Or Foundations?}

In addition to incongruent chronologies and incompleteness, the book seems confused about its purpose(s).

For instance, the book's overtly declared purpose is striving for a theory of "philanthropy," which is worthwhile and could be helpful. However, as the book progresses, what emerges instead is more like a critique of and recommendations for limited uses of foundations specifically - not philanthropy generally. There is no overt explanation I noted for the change or for not recognizing distinctions between philanthropy and foundations, except for a very early descriptive reference (19) that does not carry through the book. This may be either a subtle bait and switch or a general conception of philanthropy and foundations and their respective manifestations as if they are interchangeable, and the author knows they are not. In no small part, there are vast exercises of philanthropy beyond the formalized structure of a foundation.

So instead of a theory of philanthropy, what the book seems to provide is a perspective on foundations and proposed limited circumstances under which they should be permitted: having at least $\$ 50$ or $\$ 100$ million in assets, existing for no more than 50 or 100 years, operating only in pursuit of "discovery" (preferably with oversight by panels of expert peers) and/or for the benefit of civil society's infrastructure in securing basic liberties for future generations, and doing so without charitable deductions. Not that these suggestions or any of them are presumptively inappropriate in their own right, but they do not constitute an objective theory of philanthropy - or even necessarily of foundations - nor do they seem to be derived from such a theory. 


\section{Theory: Of Democracy?}

Contributing to the confusion in this regard is that the book seems mostly critical of America's representative democracy.

One way in which this critique emerges is relatively direct. Foreshadowing the book's final chapter, the book appeals to Immanual Kant for the proposition that philanthropic dollars generated from the injustices of government are themselves illegitimate (112), as if to conclude that all philanthropy in the United States or at least its foundations - is rooted in injustice and economic illegitimacy. Similarly, the book in two places invokes President Theodore Roosevelt's declaration that no amount of charitable spending "'can compensate in any way for the misconduct in acquiring them'"' $(4,138)$. The implication seems to be that, in the United States, there is no such thing as an honestly hard-earned dollar by or among those with wealth or who would aspire to it.

Another way in which this confusion is manifest is in how America's federal and 50 state democracies have allowed foundations to exist and operate, which according to the book is opaque, unaccountable, controlled by donor intent, in perpetuity, with a charitable deduction subsidy, and so on - albeit thus as an "artifact of the [S]tate" and through the exercies of representative democracy. Throughout the book and especially in its final chapter, the subtle and sometimes not so subtle call seems to be for a different theory and practice of democracy rather than for a first political theory of philanthropy.

It is almost as if the book's objectives emerge through three phases. First, create a following among critics of philanthropy and/or foundations - even those whose critiques do not oppose all philanthropy and/or foundations but want them to be better. Second, help those followers conclude that philanthropy and/or foundations are failing democracy. Then, lead them to realize that democracy must be failing the American people by tolerating such institutions and practices. What follows that is hard to discern.

If that assessment is on point, then I don't understand the bait and switch. Why not take on the theory and/or practice of America's republican democracy more directly? Why work through the relatively easy target of foundations, unless it is because they are relatively easy targets?

\section{Conclusion}

This is not to suggest that American democracy or our political and economic systems and institutions cannot do better for themselves and the People they serve. They can and should do better - in so many ways. And it is the responsibility of participants to engage and improve them - not just for themselves and not at the blatant expense of others. This book certainly does so engage.

Nor is this to defend each and every foundation or exercise of philanthropy. There are abuses and misuses that need to be stopped, punished, and prevented as much as reasonably possible. But too often too many consider as abuses or misuses that which are merely different points of view, priorities, or risk tolerances, especially if they diverge from the "experts," certain policy perspectives, or some particular subset(s) of the public.

Moreover, even those in that litany of people rarely agree, which divergences are the essence of plurality and a core value, principle, and virtue of productive (especially representative) democracy in practice.

Ultimately, this book does a service in trying to elevate the lack of understanding of philanthropy and foundations in our society and systems along with the need for greater, more thoughtful attention to them. If that elevation also extends to furthering understanding of America's representative democracy in practice, it would also be a contribution.

Unfortunately, the book is too confusing, incomplete, and nuanced to conclude that it actually achieves its stated objectives, beyond fostering debate. In addition, it neglects the substantive ways in which foundations and philanthropy are not only not repugnant to and not failing America's representative democracy but are consistent with it and even exemplars of it, which is a topic for another day.

\section{Acknowledgements}

John Tyler is the General Counsel, Secretary and Chief Ethics Officer for the Ewing Marion Kauffman Foundation. He also is a lecturer at Columbia University. This piece is his work, and neither it nor its components should be attributed to either organization. Mr Tyler is grateful to the people who reviewed and provided helpful feedback on drafts of this piece, but given the potentially controversial nature of this piece he has chosen not to name. 


\section{Notes}

1 The book does not explicitly define "democracy." However, a description can be gleaned from certain observations. One is reference to a "commitment to representative government with free and fair elections" as not being sufficient (136). A second is requiring a "commitment to the equal standing of citizens and an equal respect for their interests" with both being formally equal under the law. That commitment is manifest "when all citizens possess an equal opportunity for political influence and participation." (136-37).

2 See, Tyler, John (2012), Transparency Philanthropy: Accountability, Fallacy, and Volunteerism (Philanthropy Roundtable: Washington D.C.) https://www.philanthropyroundtable.org/docs/default-source/guidebookfiles/transparency_in_philanthropy.pdf?sfvrsn=2794a740_0. 